$\begin{array}{ll}\text { Abstracta Iranica } & \begin{array}{l}\text { Abstracta Iranica } \\ \text { Revue bibliographique pour le domaine irano-aryen }\end{array} \\ & \text { Volume } \mathbf{2 6} \mid \mathbf{2 0 0 5} \\ & \text { Comptes rendus des publications de } \mathbf{2 0 0 3}\end{array}$

\title{
The Letters of Kwâja 'Ubayd Allâh Ahrâr and his Associates. Leyde, Brill, 2002.
}

\section{Denise Aigle}

\section{(2) OpenEdition}

1 Journals

\section{Édition électronique}

URL : http://journals.openedition.org/abstractairanica/2621

DOI : 10.4000/abstractairanica.2621

ISSN : 1961-960X

Éditeur :

CNRS (UMR 7528 Mondes iraniens et indiens), Éditions de l'IFRI

\section{Édition imprimée}

Date de publication : 15 mai 2005

ISSN : 0240-8910

\section{Référence électronique}

Denise Aigle, "The Letters of Kwâja 'Ubayd Allâh Ahrâr and his Associates. Leyde, Brill, 2002. ", Abstracta Iranica [En ligne], Volume 26 | 2005, document 192, mis en ligne le 08 décembre 2005, consulté le 25 septembre 2020. URL : http://journals.openedition.org/abstractairanica/2621 ; DOI : https://doi.org/ 10.4000/abstractairanica.2621

Ce document a été généré automatiquement le 25 septembre 2020.

Tous droits réservés 


\title{
The Letters of Kwâja 'Ubayd Allâh Ahrâr and his Associates. Leyde, Brill, 2002.
}

\author{
Denise Aigle
}

1 Cet ouvrage comporte deux parties principales. Une partie introductive qui regroupe trois articles destinés à introduire historiquement l'édition des lettres, l'objet de la seconde partie de l'ouvrage. Dans un premier article (« The Naqshbandīya and Khwāja 'Ubayd Allāh Ahrār », pp. 1-22), Jo-Ann Gross décrit le rôle fondamental joué par Hูwāja Ahrār dans le développement de l'ordre naqšbandī qui se trouva alors plus centralisé et dont les membres s'investirent dans les structures économiques et sociales de l'Asie centrale. Elle montre que des liens plus étroits furent tissés avec les autorités politiques et avec les élites culturelles de Hérat et que, finalement, les membres de la țarīqa finirent par s'intégrer dans le milieu urbain. Dans le second article ( $"$ The Majmü'a-yi murāsalāt as a Source for the History of Mawarannahr and Khurāsān in the Late Timurid Period", pp. 23-56) J.-A.G. montre la valeur historique importante des 257 lettres autographes de $\mathrm{H}^{\mathrm{w}}$ āja Aḥār et de ses proches, en particulier en ce qui concerne l'histoire économique et idéologique de l'ordre naqšbandī, ainsi que pour reconstituer les contacts entre le Khorassan et la Transoxiane. L'étude de ces lettres apporte des renseignements précieux sur le rôle religieux, politique et économique de ces cheikhs soufis qui avaient des activités non seulement dans les Hৈ̄ānqāhs, les madrasas, mais aussi dans les villes et dans le commerce (sur ce point voir J. Paul, Die politische und soziale Bedeutung der Naqšbandiyya in Mittelasien im 15. Jahrhundert, Berlin/New York, Walter de Gruyter, 1991). Un troisième chapitre ("The Manuscript and its Authors», pp. 56-90), rédigé par Asom Urunbaev, est consacré à la tradition manuscrite des lettres. Dans la seconde partie de l'ouvrage on trouvera l'édition des lettres qui sont également traduites en anglais et annotées. Ce livre, qui est un apport important à tous ceux qui s'intéressent à l'histoire des Timourides, comporte plusieurs index très utiles dont les auteurs ont eu la bonne idée de rédiger deux versions, l'une en anglais (pp. 439-448) et l'autre en persan (pp. 449-469). On trouvera également des fac-similés de manuscrits, 
des photos de différents tombeaux, des cartes et un tableau généalogique des Timourides.

INDEX

Thèmes : 4.1. Histoire médiévale

\section{AUTEURS}

DENISE AIGLE

IFPO - Damas / EPHE 